\title{
Filming As You Like It: a playful comedy becomes a problem
}

\section{Russell Jackson}

\section{(C) OpenEdition}

1 Journals

\section{Electronic version}

URL: http://journals.openedition.org/shakespeare/656

DOI: $10.4000 /$ shakespeare. 656

ISSN: 2271-6424

Publisher

Société Française Shakespeare

\section{Printed version}

Date of publication: 1 November 2005

Number of pages: $61-74$

ISBN: 2-9521475-2-3

\section{Electronic reference}

Russell Jackson, "Filming As You Like It: a playful comedy becomes a problem », Actes des congrès de la Société française Shakespeare [Online], 23 | 2005, Online since 01 January 2007, connection on 21 April 2019. URL : http://journals.openedition.org/shakespeare/656 ; DOI : 10.4000/shakespeare.656 


\section{Shakespeare et le jeu}

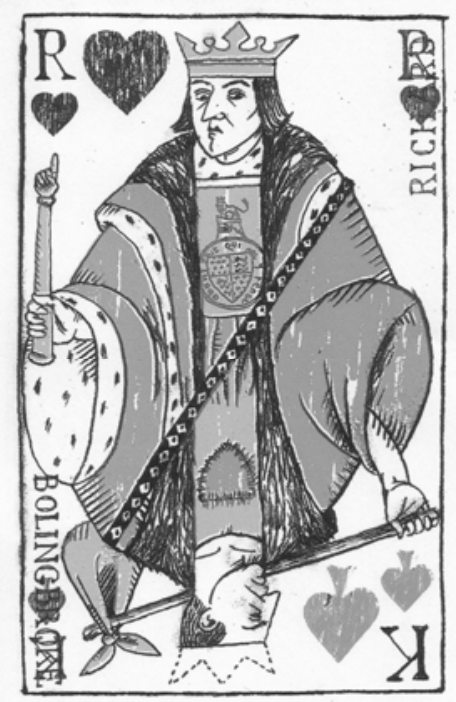

actes du Congrès organisé par la

SOCIÉTÉ FRANÇAISE SHAKESPEARE les 10, 11 et 12 mars 2005

textes réunis par Pierre KAPITANIAK sous la direction de Yves PEYRÉ 


\title{
COMITÉ SCIENTIFIQUE :
}

\author{
Margaret Jones-Davies \\ Gisèle Venet \\ Jean-Marie Maguin \\ Yves Peyré \\ François Laroque \\ Pierre Kapitaniak
}

COUVERTURE :

Edouard Lekston, King and Kusin, 2005

edlek@free.fr

conception graphique et logo

Pierre Kapitaniak

(C) 2005 Société Française Shakespeare

Institut du Monde Anglophone

Université de Paris III - Sorbonne Nouvelle

http://recherche.univ-montp3.fr/SFS/

5 rue de l'École de Médecine

75006 Paris

ISBN 2-9521475-2-3

Tous droits de traduction, de reproduction et d'adaptation réservés pour tous les pays 


\title{
FiLMING AS YOU LIKE IT: A PLAYFUL COMEDY BECOMES A PROBLEM
}

\author{
Russell JACKSON
}

The two feature films of As You Like It (Paul Czinner's in 1936 with Elisabeth Bergner, and Christine Edzard's in 1992) would seem to suggest that this comedy lends itself less easily to the medium than (say) Much Ado About Nothing or The Taming of the Shrew. What general and specific conclusions might we draw from the example of these two films and their reception?

Les deux longs métrages d'As You Like It (celui de Paul Czinner en 1936 avec Elisabeth Bergner et celui de Christine Edzard en 1992) semblent suggérer que cette comédie se prête moins facilement à ce média que, par exemple, Much Ado About Nothing ou The Taming of the Shrew. Quelles conclusions générales et spécifiques pourrait-on tirer de l'exemple de ces deux films et de leur réception?

$\mathrm{T}$ he two feature films of As You Like It made in the $20^{\text {th }}$ century could hardly be more different from one another. I intend to look at them and their reception, in the hope of casting some light on the different kinds of problem the play has presented in the cinema in two very different sets of circumstances - almost 6o years apart - and in versions undertaken with almost diametrically opposed theories of film-making. The question of making the play's setting 'real' is equally problematic in both films, and each film sets out to present what are (perhaps unsurprisingly) very different versions of a 'real' woman in Rosalind. Examining the reception of both films, this paper argues that from their seemingly opposed directions the two films meet in the same impasse, and that the problem of finding expression for Rosalind's gamesomeness is compounded by a fundamental difficulty in creating a space - a world - in which that quality can affect spectators in the cinema.

The film released in 1936, directed by Paul Czinner and starring his wife, the Austrian actress Elisabeth Bergner, with Laurence Olivier as Orlando, is a grand affair. Publicity claimed that the forest set was 300 feet long and built across two large sound stages at Elstree, making it the largest exterior set ever constructed in a British studio. The star and her husband had fled Nazi Germany (Bergner was Jewish) trailing clouds of glamour, and with firmly established stage and film careers to 
their credit. Bergner had played Rosalind on the German-speaking stage countless times since 1925 - as publicists need to give figures, though, it was claimed that she had performed the role 600 times, a figure probably not too wide of the mark. Czinner's film was announced as having cost $£ 150,000$ - in other words, as being a production on the extravagant scale that the Hollywood studios and (in Great Britain) Alexander Korda were establishing as appropriate for what were known in the trade as 'prestige' products: lavish adaptations of high-status literary or theatrical properties that would repay the producers in prestige if not at the box-office. The cast included wellknown names from British 'classical' theatre - among them Felix Aylmer, Leon Quatermaine and John Laurie - and the technical credits included designs by the Russian émigré Lazare Meerson and music by William Walton, then a fashionable, up-and-coming young composer.

In 1992 Christine Edzard's As You Like It, produced on a shoestring and filmed on a vacant plot of land adjacent to her company's studios in the then only partially reconstructed docklands of London, had young unknowns Emma Croft and Andrew Tiernan as Rosalind and Orlando (Tiernan had appeared in Derek Jarman's Edward II, but Croft had no screen credits). The cast included some names familiar in British and Irish theatre, film and television - Celia Bannerman, Cyril Cusack, Griff Rhys-Jones, Miriam Margolyes - but apart from Edward Fox, no-one with a high profile in international cinema. Edzard, a partner in Sands Films, had achieved critical success with her adaptation in two parts of Little Dorrit (1987) and The Fool (1990) and has dedicated herself to working outside the artistic constraints that invariably go with major commercial financing. Not only was the Dickens film in two parts (defying normal box-office wisdom) but it was far from the familiar period pictorialism associated with conventional British 'heritage' movie-making: there was nothing seductive in its recreation of a Victorian world. Her modern-dress version of the As You Like It, with significant and obvious doubling for many roles, determinedly retained every reference to trees, deer and streams despite its urban wasteland setting. Edzard's version refuses to offer a benign pastoral space in which games of love might be played. 
In this Arden, the weather is never kind, and the exiles live in polythene tents and cardboard boxes like the homeless whose conspicuous appearance on the streets of London was a distinguishing feature of late (and post-) Thatcherite England. Czinner's fantastic forest had been unmistakably built on a sound stage, with the usual false acoustic that accompanies the technique, while Edzard's not only lacks all but the scraggiest vegetation but has a soundtrack that seems to accept - indeed amplify - the kind of background noise (aircraft, traffic etc.) that sound recordists and editors usually strive to eliminate from location footage. Edzard's film in fact begins with 'rural' sounds juxtaposed with this urban murmuring, as we look at the titles against mirrored walls and doors with a shadowy representation of foliage. Jacques (Edward Fox) speaks the 'Seven Ages' as if in a prologue - the speech is heard again later in its appropriate place - and it is not easy to tell when one is seeing Fox directly or reflected. From the very beginning Edzard's is one the most Brechtian Shakespeare films yet released commercially, refusing to let the viewer relax into any kind of aesthetic comfort until the very end, and even then withholding any suggestion of magic. There is no Hymen in her forest, and the concluding scene returns us to the merchant bank, decked in meagrely festive mood with plastic sheeting.

However, the forest in Czinner's As You Like It is neither less stylised nor more 'real' than Edzard's. Its fantastic palace set is as unmistakably artificial as the woodland: both are comparable to Anton Grot's sets for Max Reinhardt and William Dieterle's 1935 Midsummer Night's Dream. It takes its place alongside the many distinguished films where the elaborate artifice by which quasi-realistic effects are produced takes the viewer into a new kind of hyper-reality, where we take pleasure in the devices themselves. A survey of such films would include several degrees and varieties of self-consciously elaborated 'realism' - from films where the effect is convincing but our knowledge of the artifice is a subordinate pleasure (the 'Boulevard du Crime' in Marcel Carné's Les Enfants du Paradis, for example) to those where a lavishly built set allows a degree of stylisation and 'mood' unavailable in a real location (Murnau's Sunrise, Lang's M), and those where a 
specific aesthetic effect from another visual medium is to be evoked (Korda's Rembrandt, Feyder's La Kermesse Hérö̈que, Olivier's Henry V). I've restricted my handful of examples to films of the 1920s40s, more or less adjacent in date to Czinner's. If we were to consider science-fiction or fantasy films, then the range can be extended to include the Busby Berkeley and Astaire-Rogers musicals, or Metropolis and its more recent descendants, such as Bladerunner or Batman. This isn't a paper on cinema history: I just want to suggest the variety of artificial realities available. They seem to say 'Look how carefully we've constructed a believable unreality.'

There are peasants and peasant-like activities in Czinner's film but these suggest realism vitiated by fancy rather than fantasy supported by tantalising glimpses of the real. In the opening scene the Dubois farmyard (like the whole film) is liberally provided with livestock, and Orlando and Adam are discovered seated at the noontide meal with a dozen or so farmhands, but there is no sense of a real rural economy. The barnyard is well furnished with chickens and other livestock, and in the forest of Arden the grotesquely hirsute Corin and his fleece-wrapped colleagues tend a flock of sheep of a size appropriate for Australia. Corin even pushes a miniscule handcart which seems designed simply for the transporting of a single fleece at a time - and in fact is only there so Celia can be trundled off in it.

Contemporary reviewers discussed the 1936 As You Like It largely in terms of the appropriateness of adapting Shakespeare to the cinema, the extent to which it might be expected to succeed as popular entertainment - and, of course, Bergner. Synchronised dialogue might be expected to allow a more satisfactory treatment of the plays on the screen - or perhaps not. The pomp and circumstance of the major 'prestige' films, and the showcasing of the star performers were regarded in some quarters as a return to the old pictorial and actormanagerial methods that reformers inspired by Granville-Barker and Jaques Copeau had made to seem stale and otiose during the century's first two decades. The Manchester Guardian hailed the film as 'the first attempt to put Shakespeare on the screen naturally, and with dignity,' but then qualified this with the reflection that 'a little less dignity might 
at times have been a good thing, for the production is apt to be more Victorian than Elizabethan in spirit.' (4 September 1936) For the most part, though, the sets and costumes were acknowledged as accomplished if a little over-elaborate - unfortunately the same was said about the leading lady. Bergner's exotic accent either charmed or confused (one only has to hear her speak 'the howling of Irish wolves' to hear what was wrong) and, interestingly, more than one reviewer found her inappropriately foreign on another count: she was 'too elfin, not nearly robust enough to accord with our usual English conception of this enterprising girl who sets off with a doublet and hose to look for her lover in the forest of Arden.' (Yorkshire Post, 4 September 1936) J. M. Barrie's involvement in the film - the extent of which is not entirely clear - led some to the inevitable comparisons. Bergner 'makes of Rosalind a shallow, childlike character, posturing through some dreamlike adventure in the Never-Neverland.' (Morning Post, 4 September 1936) For the Daily Telegraph, which admired her, Bergner had been successful despite her accent and despite the fact that her appearance, her mannerisms, her technique [...] are all essentially modern.' (7 September 1936) The Manchester Guardian, whose views on the Victorian element of the production have been quoted already, suggested that Bergner was sometimes too elaborate in the way she would 'draw out the lines as if they were threads upon which she was braiding her thoughts,' producing too 'sophisticated' and 'skittish' an effect. 'But she creates a Rosalind who is tender and roguish by turns and more lively than any we have seen.'

A very few critics, at least among those I have been able to read, noticed (or thought fit to mention) the oddest aspect of Bergner's performance: its sexiness. Given that this was a famous element of her appeal as acknowledged by German critics and admirers, the lack of response may well indicate a cultural difference, an English sense of proper restraint. As Stephen M. Buhler observes, 'Bergner's performance, intended to be reassuringly feminine, quickly become irritating in the context,' and Czinner may well have underestimated the British audience's readiness to accept 'gender-bending', given the 
popularity of Marlene Dietrich and Greta Garbo ${ }^{1}$. Raymond Mortimer in the New Statesman and Nation moved directly to the nub of the matter: 'Miss Bergner's gravest mistake is that she has taken from Rosalind her innocence [...] the smile at moments lengthens to a leer; the jerkined girl weighs the luscious Orlando with too greedy and too knowing an eye, and we feel that she will reveal herself a witch and gobble him up. Peter Pan has got mixed up with something out of Strindberg.' (12 September 1936)

Perhaps the single most eloquent and revealing document of Bergner's appeal to at least the men in her 'home' audience is provided by Thomas Eloesser's hagiographic pamphlet, Elisabeth Bergner, published in Berlin in 1927. The author admits that there's a good deal of Eros in Bergner's appeal, in a passage that offers almost limitless opportunities for meditating on the phenomenon of the male gaze:

Bergner is the most charming and complete edition of the femmeenfant, and I hope that it will be a long time before we have finished reading her. A child that every man wishes to adopt, but in whom he also thinks - not without a special tenderness - of the woman. And Bergner is a witch, who perhaps she ought to be burned at the stake in good time like her saint Joan; for she is a ghost, a spirit of the air, a Puck, an Ariel, who unsettles and preoccupies a great, earnest, hardworking city, who confuses the minds and even the senses of people and not only those of the young and the men. ${ }^{2}$

For fem me-enfant, then, we should read fem me fatale. Bergner is book we read, a child a man might wish to adopt, a woman he fancies and as she is also a threat to the seriousness of the city - a witch he just might have to burn at the stake. Duality is an inadequate term for such a polsyemous, polyandrous being, who goes a few steps beyond the messianic virgin/ apocalyptic whore figure represented memorably in the two Marias of Fritz Lang's Metropolis. It's hardly surprising that the frontispiece to Eloesser's book should show Bergner as Saint Joan, sitting meekly before her judges but with her robe carefully arranged to display her shapely legs.

\footnotetext{
${ }^{1}$ Stephen M. Buhler, Shakespeare in the Cinema. Ocular Proof, New York, State University of New York Press, 2002, p. 131-2

${ }^{2}$ Arthur Eloesser, Elisabeth Bergner, Williams und Co. Verlag, Berlin-Charlottenburg, 1927, p. 79-80 (my translation).
} 
Her Rosalind costume, worn with minor variations (and presumably in successive editions) from 1923 to 1936, invariably consisted of a russet tunic resembling a gym-slip, worn over a softcollared shirt, tights of the same colour with very short shorts worn over them, and dainty lace-up ankle boots. This is essentially what she wears in the film, and (as a reporter in the Screen Pictorial observed) 'her limbs [...] are at once the crazy envy and hopeless obsession of every chorus girl in London' (April 1936) Her coiffure remained defiantly girlish in a Garbo-esque style. Orlando's failure to recognise Ganymede as a boy - if not as a princess - could only be explained by the elaborateness of Rosalind's court costume and his acceptance that boy-girls are a fact of life.

One witness can stand for many as representing the effect of her stage performances in the role. Herbert Ihering, describing Bergner at the Lessing-Theater in Berlin in 1923, celebrates the Audience's delight 'as the words flowed through the relaxed body':

We were enchanted by the way everything remained in a single stream of creativity. Elisabeth Bergner spun into one another shame and jubilation, boyishness and girlishness. She swayed at the knees, and an emotion was illuminated. She held out her hands tentatively, and a joke was made tangible. Her voice broke, and one experienced the double transformation: from the girl into the boy and from the boy into the girl he was playing. An exhilarating experience. ${ }^{3}$

Ihering was a demanding judge of acting, but like many other critics, he was fascinated by the apparently uninhibited physical expressiveness of Bergner's performances. After her arrival in Britain it was her performance as the charmingly feckless and clinging gamine in an adaptation of Margaret Kennedy's novel Escape Me Never that brought Bergner her first great success. A film of As You Like It would both preserve her most famous performance, bringing it to a new audience - and perhaps also (though this was of course not mentioned) it might well represent her last appearance in the role. After all, at the age of 39 and after some 14 years in the role, her performance of innocence was beginning to look a little too experienced.

3 Herbert Ihering, Berliner Börsen-Courier, 25 April 1923 (my translation). 
The fact that the film represents a record of a famous and by now perhaps over-worked performance may explain one of its odder qualities: the lack of contact between Rosalind and Orlando. Olivier did not enjoy his experience, and he complained that Bergner did not do him the customary courtesy of reading in her lines 'off camera' when appropriate ${ }^{4}$. Rosalind as Ganymede adopts a deep, throaty voice that makes her seem very bossy indeed. (And has an echo of Dietrich, too.) When Ganymede is impersonating Rosalind, the voice is lighter, with a fluty tone that may well be a Viennese mannerism, but the element of putting Orlando in his place still seems to predominate. Armed with a supple branch with a single leaf on the end, which she deploys as if it were an instrument of mild if not quite titillating chastisement, this Ganymede/Rosalind is a wistfully stern taskmistress. There's no sense that Orlando finds this anything other than peculiar - he certainly doesn't for a moment look as though he might fancy the figure before him - and a level of complexity that performances in the last two decades have explored is altogether absent. Bergner as Ganymede may well be appealing more to the cinema audience than to Orlando. It is the audience (and Celia) who witness the apogee of her love-sickness, the forward roll she executes to demonstrate how many fathom deep she is in love. Meanwhile Orlando has to act opposite something called 'Bergner's Rosalind' rather than an interpretation that might be altered or developed by whatever he does.

The conclusions I would draw from the reception of Czinner's film can be summarized briefly. Reviewers debated the appropriateness of the newly-enhanced medium for performing Shakespeare, and the degree and kind of scenic artifice on show. They were divided - and often one was unsure in his or her own judgement - about the appropriateness of this actress's way of performing a role that had an

\footnotetext{
4 On Bergner and Olivier, see John Cottrell, Laurence Olivier, Weidenfeld and Nicolson, London, 1975, p. 101-3, and Anthony Holden, Olivier, Weidenfeld and Nicolson, London, 1988, p. 95-7. Holden's account reports Bergner's insistence (in an interview with the biographer) that Olivier treated her and her husband condescendingly as foreigners. The actor 'was not charming or friendly to work with.' For her part, Bergner seems to have taken to arriving no earlier than lunchtime, while Olivier was anxious to get back to London to rest before playing in Romeo and Juliet in the evening! Neither of the actors refer to the experience in their respective autobiographies.
} 
iconic status in the English-speaking theatre. Rosalind was also a longestablished symbol of what used to be called 'English womanhood', pure, joyful and decorous even when relatively uninhibited. The physical energy and verbal virtuosity of the performance - although the latter is somewhat clouded by the accent problem - were not doubted, but critics were disturbed by the kind of sophistication that Rosalind is given. Only a very few connected this directly to the sexual dimension of Bergner's performance, which in appearance and body language was more outspoken that they were used to in native actresses' performances of this - or for that matter, most other roles. This was not a conventional high-spirited but chaste young princess. At the same time, what Graham Greene called 'girlish games of touchwood among the trees' seemed unconvincing because of the lack of genuine youthfulness and (to Greene's mind) had been inserted at the expense of the lines themselves. ${ }^{5}$

The reception I have described so far documents some tensions and anxieties in English criticism of performances of cross-dressed Shakespearean heroines - and Rosalind in particular - in the 1930s. In particular, the role seems to have drawn attention to a 'fault-line' in discourses of stardom, sexuality, national cultural identity and 'heritage', and the hierarchy of the performing media. When we move to the case of Christine Edzard's 1992 film, the situation is somewhat simpler, if only because stardom is not an issue in responses to her Rosalind, Emma Croft, except in the inverted sense that the director has chosen to turn her back on the star phenomenon, and that consequently it becomes an issue in the film's presentation of itself to the public. An important difference between the two situations, though, is that whereas Czinner's film offers reassurance and seeks approval as doing the play justice in terms thought acceptable to the work of the national poet, Edzard's challenges conventions as to what is necessary and appropriate.

In the presentation of Rosalind, Edzard removes the role as far as possible not only from eroticism but from common notions of

\footnotetext{
5 Graham Greene, review in the Spectator, 11 September 1936, in The Graham Greene Film Reader: Morning sin the Dark, ed. David Parkinson, Carcanet, Manchester, 193, p.138
} 
credibility. Rosalind's behaviour is unequivocally out of place in word and in deed. Reviewers who believed that this 'Ganymede' passed for a boy were in a minority. The Evening Standard complained that Croft 'dive[d] headfirst into the mistake of becoming a more convincing boy than a girl.' (8 October 1992) But as another reviewer asked, echoing the majority of the press, 'would anyone today really mistake a girl for a boy just because she wears jeans and an anorak?' (Jew ish Chronicle, 16 October 1992) Time Out insisted that the disguise simply meant her adopting the same outfit as 'countless modern women.' (7 October 1992) In fact, the problem may be subtler. Modern-dress performances of the disguised Julia in The Two Gentlemen of Verona have adopted just such a subterfuge convincingly. In that play, though, the disguise is hardly revelled in, and is much more a simple element of the plot, assumed for a comparatively short portion of the play. It is the need for Rosalind to stay disguised as Ganymede for a long time, and to perform femininity in Ganymede's impersonation of 'Rosalind', that put the strain on Croft's allegedly impenetrable accoutrements. The script's kind of gamesomeness is hard for Croft to achieve in the outfit associated with modern disaffected youth. It's almost as though one were to ask the young Marlon Brando, in his longshoreman's outfit from $O n$ the Waterfront, to perform a role with the sophisticated verbal elaboration of Mercutio or Berowne. The lessons to be drawn here may be somewhat elementary: there is no single, simple concept identifiable as 'modern dress'. Instead, there are as many kinds of dress, from whatever period, as there are kinds of behaviour and social situation. Nor is there a stable and simple definition of 'modern woman' which we can ask the actress who plays Ganymede's 'Rosalind' to imitate. Nevertheless, an unavoidable requirement is that the chosen model should accommodate the wit and the playfulness of at least two dramatic characters at once.

Rosalind also needs an appropriate and accommodating space in which to be playful. The strongest condemnation of this aspect of the film was probably that of the British edition of the popular movie magazine Empire, which condemned the director for choosing 'glibness over theatrical sense' and insisted that the 'biggest problem' 
was that of reconciling the grimness of the environment with the libidinous joie de vivre of the play.' This was 'the ugliest production of the play imaginable.' (October 1992) Edzard's film has had its defenders, notably in two subtle and sensitive articles by Patricia Lennox and Amelia Mariette. ${ }^{6}$ Lennox rightly points out that the camera makes the most of a wonderful variety of textures in the old wooden fences, stone walls, and piles of industrial rubble,' and praises the script's contribution by deft cuts and transpositions to the sense of movement and variety achieved without overloading the film with intrusive visual images.7 Mariette invokes the specific juncture in politics at which the film was produced: the setting 'evokes a sense of contemporary crisis, a historical moment at which "nature" has been distorted and compromised and hope in a better future has been eroded'8. However, I remain unconvinced that the film's transformation of Arden into an urban wasteland is as socially useful as Edzard clearly thought it must be. In one interview she claimed that the transposition was 'a straightforward reading' and that it recommended itself 'because it works.' She felt that the forest had a contemporary equivalent in what she called 'urban alternative living and all that sort of thing.' (Time Out, 7 October 1992) This seems unfortunately patronising. No-one who had to live in a cardboard box in a freezing winter would take that seriously, and many critics have not been persuaded that the film's politics are anything less than jejeune - bad people run corporations, live in bank foyers and wear suits, and good people live in puddles and eat what must (given the

\footnotetext{
${ }^{6}$ Patricia Lennox, 'A Girl's Got to Eat: Christine Edzard's Film of As You Like It,' in Transforming Shakespeare. Contemporary Women's Re-Visions in Literature and Performance, New York, St Martin's Press, 1999, p. 52-64; Amelia Mariette, 'Urban Dystopias: Re-approaching Christine Edzard's As You Like It, in Mark Thornton Burnett and Ramona Wray, eds., Shakespeare, Film, Fin de Siècle, Houndmills, Basingstoke, Macmillan Press, 2000, p. 73-88. Two examples of this uncertainty about a clearly imaginative and well-intentioned film will stand for several others: Kenneth Rothwell, $A$ History of Shakespeare on the Screen, Cambridge, C.U.P., 2nd edition, 2004, p. 208-9; and Michael Hattaway, 'The Comedies on Film' in Jackson, ed. The Cambridge Companion to Shakespeare on Film, p. 94-5. Michael Anderegg offers a succinct discussion of Czinner's film, but it is perhaps on account of its very limited release and subsequent currency that he makes no mention at all of Edzard's: Cinematic Shakespeare, Lanham, Boulder, New York, Toronto and Oxford, 2004, p. 99.

${ }^{7}$ Lennox, 'A Girl's Got to Eat...', p. 57; 56.

8 Mariette, 'Urban Dystopias...', p. 76.
} 
lack of venison) be stolen from supermarkets. Quite how the cabman's shelter (with a parked taxi - who owns it?) inhabited by Celia and Rosalind, and the caravan in which Audrey runs her café fit into the scheme of urban/sylvan politics I am at a loss to explain. It's as though Edzard wants to have her cake (or slice of bread and tomato-ketchup) and eat it: the film is confrontational about creating a 'real' world of modern urban blight, and only playful when it suits the director's turn. Whether one prefers this to the archly pastoral greenery created for Bergner's hyper-playful Ganymede is perhaps a matter of taste, but like all tastes it's historically and culturally contingent.

Creating a comic world on film for any of the Shakespeare plays is in fact very difficult, whether one's expectations are those of the 1930 - accommodating a star performer, showing 'respect' for the traditions accumulated by the play, and bidding for success as a prestige film - or of the 1990s, when social purpose and credibility may predominate. In this respect, it's interesting that Branagh's commercially successful Much Ado About Nothing (1993) was a deeply unfashionable film, at least among academics. The disenchanted response may be summarised briefly: the people in the film are all too happy, there's too much on-screen laughter and that isn't a real Messina at any real date. (There are other more serious problems concerning the extent to which Claudio is let off lightly.) Similar responses were received by the same director's Love's Labour's Lost (although this was a frank pastiche of Hollywood musical comedy) and Michael Hoffman's Tuscan A Midsummer Night's Dream. To greater or lesser degree and with varying artistic and box-office success all of these sought to establish a playful world, in which gamesome behaviour could be celebrated and accommodated. This suggests by way of conclusion a question that takes us into a slightly different area: is there a difference between making a playful world for Shakespeare on stage and on film?

A world created on stage is, like the contract between performer and audience, always provisional. We can vary the nature of the one and the terms of the other in the course of a performance without losing (should we want to keep it) a sense of coherence. In film, which 
commandeers the audience's control over time and space to a far greater degree, disruptions of this kind are a good deal harder to renegotiate, unless (like many nouvelle vague films) one is insisting on a purposeful alienation effect - and then the reasons for it need to be clear. It may be that the real problem of filming As You Like It is the cinema's problem with saying 'It's only a play.' Czinner's film concludes with a version of the play's epilogue in which Bergner appears first as Rosalind in her wedding dress, then (by a simple trick) mutates into Ganymede, switch in hand, before returning for the final lines to female form. I can't agree with the critic in Sight and Sound (October 1992), Ilona Halverstadt, who concluded that Edzard 'restores to filmed Shakespeare the means and immediacy of cinema,' as it seems to me that she really pushes her actors further away from the audience. However playful Emma Croft might have wanted to be, as she throws stones and freewheels around the dusty puddle-strewn lot that is her Arden, taunting Orlando, in the last analysis she cannot defeat the insistent drabness surrounding her. On a stage, even if a confrontational director and designer have heaped the forest with cinders and ashes, and taken extreme measures to deny the audience any sense of trees, Rosalind is in control - the actors can talk to us, and the set can't. Emma Croft's plight, paradoxically, is the same as that of Bergner, surrounded by bosky fantasy on her Elstree soundstage.

Perhaps the problem also stems from the peculiar nature of the imagined location in this play. The forest is a liminal space, representing a state through which the characters must pass on their way to various kinds and degrees of maturity. Much more than the magic wood of A Midsummer Night's Dream, this is imagined as a real place, and the incidents and circumstances that affect the characters, although romantic, are not magic. ${ }^{9}$ Rosalind's claim to be able to conjure, and to have learned to conjure by having 'conversed with a magician' (v.iii.20) is no more a statement of fact than her pretence that she is 'Ganymede'. In the theatre the nature of the space occupied

\footnotetext{
${ }^{9}$ Robert Smallwood provides a concise summary of the features of this 'shape-shifting' forest in his account of Stratford post-war productions, As You Like It in the series 'Shakespeare at Stratford', London, The Arden Shakespeare, 2003, p. 70-1.
} 
by the actors is always negotiable, whether or no there are 'trees' of some kind. The negotiations continue throughout the performance, but in the cinema the scope for such negotiation is more limited. Cinematic fantasy has the property of commanding conviction on levels similar to but not identical with those of the theatre. Once we establish that a particular place 'is' the forest of Arden, the illusion is more concrete and harder to dispel or vary than theatrical make-believe without some acknowledgement of the shifting perception from within the film - and its dialogue. When the forest is reached, the characters treat it as a given, and the spoken language of the text, however adapted and abbreviated, tends to predominate in a film where Rosalind's behaviour towards her lover is primarily verbal. Both Emma Croft and Elisabeth Bergner tend to move as expansively as possible during their wooing scenes, as if to find a hectic physical equivalent for the brilliance of the dialogue. The camera seems to look on unpityingly, far more reserved than any 'live' theatre spectator. Creation of the sense of a playing space, a playground for Rosalind's game - is by far the hardest task faced by those who undertake to film As You Like It.

Russell JACKSON University of Birmingham 